\title{
Islam dan Nasionalisme: \\ Pandangan Pembaharu Pendidikan Islam \\ Ahmad Dahlan dan Abdulwahab Khasbullah
}

\author{
Iwan Setiawan \\ Universitas Aisyiyah Yogyakarta \\ Iwan@unisayogya.ac.id
}

Naskah diterima: 26 Desember 2017, direvisi:11 Januari 2018; disetujui: 29 Januari 2018

\begin{abstract}
S
Until this day, the dichotomy between "Islam" and "Nationalist" is still going on. The dichotomy makes moslems uncomfortable in their social communities, particularly when they meet community with different religions in Indonesia. Finally, the dichotomy creates a big question, "Is Islam not nationalist?" This article tries to answer a question "Is a Moslem a nationalist?" by looking back the history of two founding fathers of the islamic education and nation heroes. They are Ahmad Dahlan and Abdulwahab Khasbullah, the founders of two the biggest Islamic organization in Indonesa, Muhammadiyah and Nahdlatul Ulama (NU). By studying about two formers of islamic education in the colonalism era or before the independence of Indonesia, we can answer and explain the above question. The purpose of this article is to proof that the islamic leaders, Ahmad Dahlan and Abdulwahab Khasbullah are nationalists. This research was a Library Research whereas the data were taken through books, journals, magazines and news papers. Library study is also called as literature study.
\end{abstract}

Keywords : Islamic Education Reformer, Nationalism, Ahmad Dahlan, Abdulwahab Khasbullah.

\begin{abstract}
ABSTRAK
Sampai hari ini, dikotomi antara "Islam" dan "Nasionalis" masih terjadi. Dikotomi ini menjadikan seorang Muslim merasa tidak nyaman dalam pergaulan di masyarakat, khususnya saat bertemu dengan kelompok yang berbeda agama. Pada akhirnya, dikotomi ini menjadikan sebuah pertanyaan "Apakah menjadi Muslim bisa menjadi Nasionalis"? Artikel akan menjawab pertanyaan diatas dengan melihat sejarah dua tokoh pendidikan Islam dan Pahlawan Nasional. Mereka adalah Ahmad Dahlan dan Abdulwahab Khasbullah, dua pendiri organisasi terbesar di Indonesia, Muhammadiyah dan Nahdlatul Ulama. Dengan meneliti tentang dua tokoh Pendidikan Islam di masa Kolonial Belanda sebelum era kemerdekaan, kita bisa menemukan jawaban atas pertanyaan diatas. Tujuan artikel ini untuk menunjukkan bahwa tokoh Islam bernama Ahmad Dahlan dan Abdulwahab Khasbullah adalah seorang Nasionalis. Penelitian ini merupakan Library Research, dimana sumber pustaka diambil dari buku-buku, jurnal, majalah dan Koran. Library Research juga sering disebut dengan istilah penelitian Kepustakaan.
\end{abstract}

Kata Kunci : Pembaharu Pendidikan Islam, Nasionalisme, Ahmad Dahlan, Abdulwahab Khasbullah. 


\section{Pendahuluan}

Merekatkan Islam dan keindonesiaan adalah sebuah proyek besar cendekiawan Muslim Indonesia sejak tahun 1970-an. Salah satu usahanya dengan mencoba membuka kembali akar-akar nasionalisme awal Indonesia dalam mengusir penjajah di bumi Nusantara ini. Islam dan keindonesiaan merupakan suatu formula untuk menjadikan Islam sebagai bagian dari bangsa yang memiliki rasa cinta tanah air dan keinginan yang sama untuk memajukan bangsa ini, tanpa ada stigma atas perjuangan umat Islam di tanah air ini.

Memahami "umat Islam" Islam sebagai bagian dari kesadaran akan rasa nasionalisme merupakan usaha merekatkan kembali akar ke-sejarahan Islam di masa lalu. Islam sebagai bagian dari kebangkitan nasionalisme Indonesia akan mampu membuka sekat-sekat dikotomi yang selama ini kerap mengganggu kerukunan antar warga negara Indonesia, khususnya bila dikaitkan dengan sekat antara umat Islam dan kelompok nasionalis (Fealey, 1997: 90) ada stigma berkaitan dengan hubungan umat Islam dan kelompok nasionalis yang berujung pada pertentangan paham antara keduanya (Latif 2013, $85)$.

Walaupun kemunculan wacana Nasionalis-Islamis tidak terlalu gencar, tetapi gema dikotomi antara "Allahu Akbar" dan "merdeka" mengingatkan kita kembali pada perdebatan dalam rapat konstituante antara fraksi Islam dan nasionalis tentang pemberlakuan syariat Islam (Maarif 2017, 20). Pertanyaan inilah yang kerap menjadikan kelompok Islam dalam tataran pergaulan di Indonesia ini sering dipojokkan. Dalam kurun lima puluh tahun, stigma akan Islam dan cita-cita kebangsaan masih dapat kita rasakan.

Adanya beberapa peristiwa pemberontakan di republik ini yang dilakukan oleh beberapa kelompok Islam juga menjadi stigma bagi umat Islam. Pertistiwa PRRI di Sumatera Barat, Darul Islam di Jawa Barat dan Sulawesi Selatan menjadi catatan hitam bagi gerakan Islam. Al-Chaidar (2013) menjelaskan beberapa peristiwa ini sering menjadikan hubungan antara pengauasa dan umat Islam sedikit renggang dan terkesan dibesar-besarkan dan menjadikan rasa nasionalisme umat Islam dipertanyakan.

Dalam tulisan ini akan diuraikan bagaimana pandangan Ahmad Dahlan dan Wahab Khasbullah tentang cita-cita kebangsaan mereka dan bagaimana usaha mereka dalam menuju kemerdekaan Indonesia. Untuk itu, menelusuri pandangan hidup para pembaharu pendidikan Islam, lewat Ahmad Dahlan dan Wahab Khasbullah merupakan usaha untuk menyingkap pandangan kedua tokoh tersebut tentang nasionalisme awal Indonesia yang sebenarnya berawal dari ajaran-ajaran Islam tentang rasa cinta tanah air. 
Lewat tulisan ini penulis akan mencari jawaban atas pertanyaan, "Masih relevankah dikotomi Islam dan nasionalis, ketika tokoh-tokoh Islam sebenarnya adalah nasionalis tulen.?" Dan juga penyingkapan bagaimana rasa kebangsaan dan cinta tanah air itulah yang menjadikan para pembaharu pendidikan Islam bergiat dalam memajukan bangsanya dalam jalur pendidikan.

Dalam hal ini masih terkandung adanya prasangka bagaimana umat Islam selalu dicurigai tidak nasionalis karena selalu memiliki agenda tersembunyi untuk mendirikan negara Islam. Untuk itulah, dengan melakukan studi atas kehidupan kedua tokoh pendidikan Islam, dalam wilayah pendidikan sekolah dan pesantren inilah akan diketahui pandangan keduanya atas usaha menuju kemerdekaan Indonesia.

Islam sebagai suatu entitas kebangsaan Indonesia perlu menghindarkan diri dari anggapan dan prasangka-prasangka nasionalis dan tidak nasionalis. Karena hal ini akan menjurus kepada diskriminasi atas rasa kebangsaan yang perlu dipertanyakan dari kelompok Islam atau sebut saja kelompok santri atas kecintaannya kepada tanah airnya. Indonesia sebagai negara yang beragam etnis dan agama tetap menjadikan Ketuhanan Yang Maha Esa sebagai perekat dalam keragaman ( Wahyudi 2006, 21).

\section{Awal Kemunculan Pembaharuan Pendidikan Islam}

Jauh sebelum gerakan kemerdekaan dan kebangkitan nasionalis lewat Jong Java, Jong Selebes, Islam sebagai entitas kekuasaan dan budaya Indonesia di abad 17-18 telah menunjukkan sumbangannnya yang mengagumkan. Nuruddin al-Raniri, Abdul Rauf alSinkili dan Muhammad Yusuf al-Makassari, (Azra 1998, 166-307) sedikit contoh dari nama-nama pembawa corak pemikiran dan praktek keagamaan yang mempengaruhi warna dan produk para ulama-ulama pembawa ajaran Islam di Indonesia. Setelah Islam mengakar kuat, munculnya pesantren, (Dhofier, 1997: 31-37) Madrasah (Maksum 1999, 70) dan sekolah (Daulay 2001, 36) yang menjadi produk dari keragaman dan macam pendidikan Islam.

Madrasah Nizhamiyah di Baghdad, Irak merupakan lembaga pendidikan Islam resmi dari pemerintah yang merupakan lembaga pendidikan Islam yang pertama berdiri. Walaupun pendirian madrasah ini selain karena motivasi agama, dan motivasi ekonomi karena berkaitan dengan ketenaga-kerjaan, juga motivasi politik. Seperti membawa aliran pemikiran tertentu. Lalu berdiri madrasah yang mencontoh sistem Nizhamiyah seperti kepunyaan Mu’tazilah, Ikhwanul Safa, ahli filsafat, ahli sufi maupun ahli fiqh. 
Dalam proses Islamisasi di Indonesia abad 17-18, model madrasah Nizhamiyah yang 'Timur Tengah minded' yang mungkin terlalu modern untuk ukuran Indonesia saat itu, "dilokalkan" menjadi pesantren, dayah maupun surau (Azra 2003, 9) yang dalam pandangan para antropolog merupakan lembaga pendidikan Islam tradisional.

Lewat proses dialog antara pendidikan Islam tradisional dengan pendidikan Barat lewat Hollansche Inlandsche School (HIS), Meer Unitgebreid Lager Ondanwijs (MULO), Hoorgeie Burger School (HBS) dan Algeemene Middlbrate School (AMS) yang setara dengan SMA pada masa sekarang. Menjadikan pendidikan Islam juga mengalami modernisasi dan inovasi. Seperti adaptasi terhadap sistem pendidikan Barat; adanya kelas, kurikulum, penjenjangan usia, seragam maupun tempat duduk dilakukan untuk ikut memodernkan pendidikan Islam (Shihab 2016, 116).

\section{Sebab Kemunculan}

Apa sebab kemunculan pembaharuan pendidikan Islam di Indonesia? Di dalam tulisan ini, pembaharuan bukan berarti disebut sebagai modernisasi saja, tetapi juga perubahan pola pikir para pembaharu pendidikan Islam, semisal perubahan cara pandang mereka terhadap penjajahan.

Pertama, pembaharuan pendidikan Islam di Indonesia dimulai dari kegelisahan banyak tokoh pendidikan Islam terhadap kaum muslimin yang sangat terbelakang, khususnya di bidang pendidikan, di mana wawasan intelektual menjadi semakin sempit dan pelajaran hanya pada masalah teologi (Azra 2002, 25).

Kegelisahan ini berasal dari perjumpaan para pembaharu pendidikan Islam dengan tokoh-tokoh seperti Muhammad Ali Pasha, al-Tahtawi dan terutama oleh Jamaludddin alAfghani, Muhammad Abduh, Rasyid Ridha dan Sir Ahmad Khan, lewat bacaan ataupun perjumpaan mereka dengan proses modernisasi pendidikan, terutama di Universitas AlAzhar.

Kedua, pembaharuan pendidikan Islam juga muncul ketika ada masalah antara sekolah formal dengan sekolah informal. Sekolah formal pada masa kolonial Belanda adalah sekolah bentukan pemerintah Belanda. Di luar sekolah formal ada pesantren, dayah, surau dan nggon ngaji yang merupakan tempat belajar membaca Alquran yang bertempat di rumah-rumah penduduk.

Dikotomi antara sekolah formal yang mengajarkan pendidikan umum dengan sekolah informal yang biasanya "cuma" mengajarkan pendidikan agama menyebabkan terjadinya kesenjangan sosial. Dalam hal ini, kalangan santri yang belajar di sekolah 
informal tidak akan mampu menyaingi kaum abangan yang biasanya sekolah di sekolah formal. (Geertz, 1976: 5) A. Hasan di tahun 1930-an dalam menyikapi masalah itu pernah mengatakan "Apa boleh buat, di zaman ini , di sini belajar Bahasa Arab, tidak dapat menjadi pegawai” ( Steenbrink 1994, 195).

Ketiga, ketika pendidikan Barat tidak bersifat netral. Pendidikan Barat yang diselenggarakan oleh pihak zending dalam permulaan abad 19 sarat dengan misi penginjilan. Juga munculnya kristenisasi lewat pendirian sekolah modern Barat. JA. Van der Chijs melaporkan perjalanan pendidikan di Maluku tahun 1867, bahwa guru-guru dari Belanda selain sebagai guru sekolah juga beperan sebagai pendeta (Steenbrink 1987, 59160), dan pada akhirnya kolonial Belanda dengan penetrasi agama Kristen yang kuat mulai bermain dalam misi keagamaannya.

Keempat, adanya perjumpaan tokoh-tokoh pembaharu pendidikan Islam dengan tokoh-tokoh "nasionalis" sekuler (Zuhri 198, 40) maupun "nasionalis" religius (Jainuri 2002, 49) yang dari perjumpaan tersebut mereka mempunyai angan-angan yang sama untuk bahu membahu dalam memerdekakan Indonesia. Kerja di antara mereka itu dimulai dengan membangun atau mengadakan pembaharuan pendidikan, baik pendidikan agama maupun pendidikan umum.

Proses pendidikan baik yang dilakukan oleh Muhammadiyah dan Nahdlatul Ulama turut memberi andil bagi proses Islamisasi di Tanah Jawa. M.C Rickleft dengan tepat menjelaskan bahwa kemunculan para pembaharu pendidikan Islam seperti Ahmad Dahlan dan Abdulwahab Khasbullah mampu memberikan kekuatan bagi generasi selanjutnya untuk mengekspresikan religiustitas mereka dalam kehidupan nyata (2013, 287).

\section{Keadaan Pendidikan Islam Masa Belanda}

Dalam perjalanannya, pendirian sekolah-sekolah Islam di Nusantara tidak berjalan mulus. Ketika kolonialisme mencengkeram negeri ini, masalah pendirian sekolah merupakan masalah yang serius. Hal ini diakibatkan oleh pengalaman kolonial Belanda atas pendirian sekolah-sekolah Islam yang nyata-nyata menentang kolonialisme, walaupun tidak dengan melakukan perlawanan secara terbuka.

Adanya stigma akan pendidikan Islam sebagai bagan dari perlawanan terhadap Belanda merupakan sesuatu sejarah yang perlu disingkap. Perlawanan pendidikan Islam terhadap penjajah yang paling ringan adalah dengan pendirian sekolah-sekolah Islam, semisal pondok pesantren di pinggir kota atau bahkan di pelosok desa. 
Hal ini memperlihatkan bagaimana sebuah institusi pendidikan Islam tidak mau berdekatan dengan kekuasaan Belanda yang ada di kota, karena mereka tidak mau diaturatur oleh penjajah. Juga keberadaan doktrin dalam Islam akan kaum kafir yang harus ditolak untuk bekerjasama dengan kaum muslimin juga menjadi indikasi akan perlawanan sekolah-sekolah Islam terhadap penjajah.

Ketegangan inilah yang menjadikan sekolah-sekolah ini menjadi sulit didirikan di Nusantara. Puncak ketegangan antara pendidikan kolonial Belanda dengan pendidikan Islam adalah adanya kebijakan kolonila Belanda tentang ordonansi guru (Daya 1995, 262), di mana pengawasan dari kolonial Belanda ini mendapat perlawanan dari kaum muslimin.

Dengan adanya ordonansi guru ini, ketegangan-ketegangan antara pemerintah kolonial dan kaum muslimin memunculkan ketidaknetralan pemerintah kolonial terhadap agama, seperti dinyatakan dalam pasal 199 Konstitusi Belanda tahun 1885. Tujuan ordonansi guru adalah untuk mengendalikan pendidikan yang diselenggarakan oleh umat Islam (Setiawan 2015, 216).

Selain itu, kemunculan ordonansi ini merupakan puncak peristiwa yang terjadi dua dekade sebelumnya, yaitu reaksi terhadap pemberontakan petani di Cilegon, Banten (Jawa Barat), melawan kolonialisme tahun 1888 yang dihasut guru-guru agama maupun obsesi pemerintah kolonial Belanda lewat organisasi misionaris untuk memperluas pengaruh Kristen dan membatasi pengaruh Islam. Untuk itulah dalam masa yang sulit tersebut, kedua tokoh pendidikan Islam itu tetap berusaha memajukan Islam dan Nusantara ini dengan mendirikan dan membuat pembaharuan atas pemikiran pendidikan Islam di Nusantara.

\section{Pembaharuan Ahmad Dahlan}

Kyai Haji Ahmad Dahlan lahir pada tahun 1888 dari keluarga Muslim tradisional yang berdomisili di Kauman (Mulkhan 1990, 7), Yogyakarta. Beliau adalah ulama kharismatik dan kontroversial (Dahlan 2014,123) yang membawa semangat pembaharuan dan membawa semangat keluar dari belenggu taqlid (Syarif 2017, 76). Saat muda, ia adalah anggota aktif Jamiat Kheir (Saiman 1995, 20), gerakan pembaharuan Islam pertama di Indonesia. Tetapi perjumpaan yang paling mengesankan dan mengilhami pendirian Muhammadiyah adalah keikutsertaan dirinya di Budi Utomo dan Sarekat Islam.

Di masa mudanya, tahun 1908-1909 Ahmad Dahlan mendirikan sekolah, yakni Madrasah Ibtidaiyah (SD) dan Madrasah Diniyyah di rumahnya. Sekolah ini dikelola secara modern dengan menggunakan metode dan kurikulum baru; antara lain diajarkan 
berbagai ilmu pengetahuan yang sedang berlangsung di abad 20, juga penggunaan kursi, bangku serta kelas yang pada waktu itu masih dianggap asing. Perjumpaan Ahmad Dahlan dengan pendidikan model kolonial Belanda inilah yang memberikan sumbangsih pada pembaharuan pendidikan Islam ( Peacock 2017, 45).

Ia sangat terkesan pada model pendidikan dari kolonial Belanda. Akhirnya ia merancang pendidikan Islam model sekolah kolonial, di mana ada penjenjangan kelas, kurikulum yang jelas dan adanya seragam sekolah. Sebagai guru di sekolah Islam, Ahmad Dahlan menjadikan model "sekolah dasar Belanda dengan Bibel" dijadikan "sekolah dasar Belanda dengan Al-Quran" hal ini dilakukan Ahmad Dahlan sebagai suatu ijtihad dalam melihat suatu realitas sosial (Mulkhan 2003, 95).

Salah satu usahanya dalam memajukan pendidikan Islam adalah usahanya memperbaharui sistem pendidikan yang dualistis, yaitu antara ilmu agama dan ilmu pengetahuan umum. Ia harus menyatukan sistem pendidikan Barat yang lebih mengutamakan dan mengembangkan aspek intelektual, dan sistem pendidikan Islam yang kurang mengembangkan aspek intelektual (Lubis 1995, 102) pengembangan lain yang dilakukan Ahmad Dahlan adalah memadukan kesalehan intelektual dan kesalehan sosial (Ahmad 2015, 144).

Tahun 1912 di Yogyakarta, Ahmad Dahlan mendirikan Muhammadiyah, sebuah organisasi yang bergulat dalam masalah kesejahteraan sosial dan pendidikan. Sebagai seorang yang banyak bergaul dengan kelompok Islam kota, model pendidikan Muhammadiyah juga tidak jauh dari kesadaran Ahmad Dahlan untuk memodernkan pendidikan Islam. Tujuan pendirian Muhammadiyah tercantum dalam risalah pendek ini.

Menyebarkan pengajaran kanjeng Nabi Muhammad SAW kepada penduduk bumi putera dan memajukan hal agama Islam kepada anggota-anggotanya. Untuk mencapai ini bermaksud mendirikan lembaga-lembaga pendidikan, mengadakan rapat-rapat dan tabligh di mana dibicarakan masalah-masalah Islam, mendirikan wakaf dan masjid-masjid serta menerbitkan buku-buku, brosur-brosur, surat-surat kabar dan majalah-majalah (Noer 1996, 86).

Dengan berdirinya Muhammadiyah ini, usaha-usaha dan pemikiran Ahmad Dahlan yang pernah menjadi obsesinya mulai digulirkan dan dilaksanakan. Dengan berdirinya Muhammadiyah inilah banyak masyarakat yang mulai tertarik untuk mengikuti kegiatannya. Aspek organisasi Muhammadiyah yang menjadi organisasi legal, karena mendapat ijin dari Gubernur Jenderal Belanda, menjadikan Muhammadiyah lebih luwes bergerak, khususnya di dalam memajukan aspek sosial, ekonomi dan pendidikan 
anggotanya. Walaupun Muhammadiyah menjauhi kegiatan politik tetapi tidak berarti Ahmad Dahlan dan Muhammadiyah tidak berpolitik. Pribadi Ahmad Dahlan yang sangat terbuka dengan ide-ide orang lain menjadikan Ahmad Dahlan mudah bergaul dengan banyak orang.

Ahmad Dahlan menginginkan dan mendorong kaum muslimin untuk mengembangkan wawasan lebih luas. Ia menyarankan mereka untuk mempelajari agamaagama dan ide-ide orang lain. Ia yakin bahwa kebenaran berdasarkan wawasan yang lebih luas ini akan memberikan dukungan yang lebih besar bagi implementasi agama dalam kehidupan seseorang (Jainuri, 2002: 45). Bagi Ahmad Dahlan, untuk mencari kebenaran, orang tidak boleh merasa benar sendiri. Oleh karena itu, orang harus berani berdialog dan diskusi dengan semua pihak, walaupun dengan orang atau golongan yang bertentangan dan berbeda pendapat (Mulkan 2010, 11).

Dengan sifat yang terbuka ini menjadikan Ahmad Dahlan dan Muhammadiyah menjadi rujukan kelompok Nasionalis ataupun komunis untuk menuangkan gagasangagasan mereka tentang kemerdekaan Indonesia. Sifat terbuka ini tercermin dari kesediaan Ahmad Dahlan menerima tawaran pemimpin Indische Social Democratische Party (ISDV) (Raharjo 1999, 234) untuk berbicara di hadapan Aisyiyah, sebuah organisasi perempuan di bawah Muhammadiyah.

Walaupun keputusan ini banyak mendapat protes dari para anggota Muhammadiyah, tetapi bagi Ahmad Dahlan, pertemuan itu merupakan pembelajaran bagi kader-kader Muhammadiyah dalam menerima gagasan orang lain. Kenyataannya, sambutan kaderkader Muhammadiyah dalam memandang komunisme patut disimak. Mereka mengatakan, "Ideologi Islam merupakan pilihan yang lebih baik bagi perjuangan kemerdekaan dibandingkan komunisme."

Hadirnya pernyataan ini adalah hasil kerja dan pemikiran Ahmad Dahlan dalam menerima dan membuka pintu organisasinya terhadap dunia luar, terutama organisasi yang pro-kemerdekaan. Bahkan salah seorang anggota Muhammadiyah yang paling cemerlang, Fahruddin (lahir 1889) menjadi wartawan di koran terbitan ISDV, yaitu Islam Bergerak. Koran ini diasuh oleh Haji Misbach, seorang Muslim-Komunis (Alfian 2010, 200).

Perjumpaan Ahmad Dahlan dengan pemimpin Sarekat Islam (SI) terutama dengan jajaran pimpinan pusat SI juga menjadi pemicu rasa nasionalisme Ahmad Dahlan. Walaupun dia telah mendirikan Muhammadiyah (1912), tahun 1914-1917 ia tetap menjadi penasehat SI. Sehingga ide-ide nasionalisme untuk mencapai kemerdekaan Indonesia mulai bersemi. 
Dengan terbukanya kesadaran Ahmad Dahlan tentang pentingnya kemerdekaan Indonesia, ia memutuskan bahwa para anggota Muhammadiyah yang mendukung pada kemerdekaan Indonesia dapat menyalurkan aspirasinya lewat SI tanpa mengorbankan Muhammadiyah yang tetap pada jalur sosial dan pendidikan.

Tindakan nyata dari komitmen Ahmad Dahlan untuk kemerdekaan Indonesia adalah adanya perjanjian di tahun 1920, dimana SI membuat komitmen untuk berjuang dalam politik sementara Muhammadiyah memilih berkonsentrasi dan berjuang lewat lapangan agama, pendidikan dan sosial. Komitmen untuk berjuang dengan SI ini terlihat dari usaha Muhammadiyah mendirikan sekolah yang menyaingi Sekolah Gubermen (milik Belanda) yang merupakan cita-cita SI sejak lama Jainuri (2002) menjelaskan:

Di samping mendirikan sekolah yang mengikuti model Gubermen, Muhammadiyah dalam waktu singkat juga mendirikan sekolah yang bersifat agama. Sekolah ini, seperti madrasah diniyyah di Minangkabau yang dimaksudkan untuk mengganti dan memperbaiki pengajian Alquran yang tradisional. Untuk pengajian kitab, Muhammadiyah juga segera mencari penggantinya yang sesuai dengan tuntutan jaman modern, usaha tersebut dapat dianggap sebagai realisasi dari rencana Sarekat Islam yang semenjak 1912 berusaha mendirikan sekolah pendidikan agama, yang dapat menyaingi sekolah pendidikan guru gubermen.

Hal yang paling menonjol, sifat nasionalisme pada diri Ahmad Dahlan dan Muhammadiyah direfleksikan pada lima fase ideologi Muhammadiyah ketika awal berdiri. Lima fase ini dapat memicu permusuhan terhadap kolonial Belanda, yaitu: rasionalisme, pendidikan sebagai landasan bagi pembangunan politik, pengaruh keanggotaan kelas menengah, minat kepada budaya Jawa dan sikap yang bermusuhan terhadap doktrindoktrin asing, seperti komunisme dan Kristen.

Rasa Nasionalisme Ahmad Dahlan identik dengan gerakan dan perjuangan. Ia adalah potret seorang pejuang dan pahlawan. Kepahlawananya bukan dalam sosok prajurit yang memanggul senjata dan gugur dalam medan perang, tetapi dalam sosok kemanusiaan: ia mengabdikan dirinya kepada kepentingan dan kemaslahatan pendidikan, dakwah dan sosial keagamaan dalam wawasan kebangsaan yang kental dan integral (Ni'mah 2014, 136).

Di masa kemerdekaan, pengakuan atas jasa Ahmad Dahlan dalam usaha menuju kemerdekaan Indonesia diwujudkan dengan pemberian anugerah sebagai Pahlawan Nasional. Dalam pidato pembukaan Muktamar Muhammadiyah ke-41 si Solo, Jawa Tengah tahun 1985 Presiden Soeharto mengomentari atas usaha Muhammadiyah dalam membantu perjuangan Nasional Indonesia "Benih-benih semangat kebangsaan langsung atau tidak langsung mulai ditaburkan oleh pemimpin-pemimpin dan pemuka Muhammadiyah ke dalam sanubari rakyat Indonesia” (Saiman 1995, 56). 


\section{Pembaharuan Abdulwahab Khasbullah}

Komitmen dan rasa cinta tanah air yang tinggi dan dibuktikan dengan aktivitas mereka dalam memperjuangkan Indonesia merdeka juga muncul pada kelompok pembaharu pendidikan Islam di lingkungan pesantren. Figur Wahab Khasbullah menjadi penting untuk disimak dan dijadikan contoh yang baik. Salah satu jasa terbesar beliau adalah mendirikan Nahdlatul Ulama (NU) pada tahun 31 Januari 1926 bersama Hadlarusy Syeikh Hasyim Asy'ari. Lewat NU pulalah gerbong rasa cinta tanah air menghujam kuat dalam sanubari anggotanya (Masfiah 2016, 217).

Sebagai seorang pembaharu pendidikan Islam di lingkungan pesantren, Wahab Khasbullah (1888-1971) yang berjasa dalam membukakan diri untuk mendorong dunia pesantren dalam menerima dan mencoba melakukan "reformasi". Jasa terbesarnya adalah menguatkan posisi tawar kelompok Islam tradisionalis dari lingkungan pesantren dengan membentuk organisasi Nahdlatul Ulama (Bruinessen 2015, 46).

Sebelum Wahab Khasbullah diserahi pesantren Tambak Beras oleh ayahnya, Kyai Khasbullah, ia adalah seorang "musafir pencari ilmu"hal ini merupakan tradisi dari para santri pondok pesantren. Wahab Khasbullah juga mengikuti tradisi musafir untuk berburu ilmu di pesantren-pesantren di Jawa. Hal ini menunjukkan betapa pentingnya kegiatan mencari ilmu bagi seorang Muslim. Dalam Tradisi Pesantren, Zamakhsyarie Dhofier (2014) meringkas alur pengelanaan Wahab Khasbullah saat menjadi musafir:

Setelah mendapat ilmu dari ayahnya, Hasbullah, pemimpin pesantren Tambak Beras, Jombang. Wahab Khasbullah melanjutkan ke Pesantren Pelangitan Tuban selama 1 tahun, Pesantren Mojosari di Nganjuk selama 4 tahun, ke Pesantren Tawangsari selama 1 tahun, Pesantren Kedemangan bangkalan madura, Pesantren Branggahan Kediri selama 1 tahun dan Pesantren Tebu Ireng, Jombang. Lalu dilanjutkan ke Mekkah selama 4 tahun dan berguru kepada enam ulama ternama, mereka adalah kyai Mahfudz al-Tirmisy, Kyai Muhtaron, Syaikh Ahmad Khatib, Kyai Bakir, Kyai Asy'ari dan Syaikh Abdul Hamid.

Seperti Ahmad Dahlan yang sangat terbuka, pribadi Wahab Khasbullah yang "liberal" dalam pergaulan dan cukup vokal dalam berpendapat, hal ini mengantarkan dirinya pada organisasi yang tidak kooperatif pada kolonial Belanda, semisal SI di bawah pimpinan Cokroaminoto. Ia juga aktif dalam kelompok diskusi intelektual nasional dengan ikut menjadi anggota Indonesiche Studie Club (ISC) pimpinan Dr. Sutomo (Anam 1985, 31). Dengan pergaulan inilah yang menjadikan Wahab Khasbullah sangat paham dengan masalah modernisasi dunia dan pembaharuan pendidikan Islam. 
Di ISC ini, Wahab Khasbullah memulai usahanya untuk menggalang persatuan untuk usaha kemerdekaan Indonesia. Hal ini dilakukan dengan mempertemukan antara pemimpin-pemimpin pergerakan dengan ulama untuk mengemukakan ide-idenya dan usaha kesepahaman bersama antara pemimpin pergerakan dan kaum ulama yang agak renggang Saifuddin Zuhri (1983), mengemukakan:

Cita-citanya semakin jelas. Di samping menggalang bertemunya aspirasi Islam dan Nasionalisme, dua aspirasi dasar untuk menggalang persatuan antara potensi Islam dan kaum nasionalis sebagai kekuatan pokok bangsa Indonesia dalam menghadapi politik kolonial Belanda. Hal ini terjadi tahun 1924-an dan kita bisa bayangkan bahwa meletakkan dasar strategi paling pokok di jaman kekuasaan kolonial, bukanlah pekerjaan ringan tanpa resiko.

Dalam perjalanan sejarahnya, golongan nasionalis dan kaum ulama memang sering tidak pernah tatap muka. Tetapi, ketika terjadi dialog antara pemimpin pergerakan yang identik dengan nasionalis dengan kaum ulama, sebenarnya ada sebuah kesamaan pandangan tentang keinginan mereka untuk memerdekakan Indonesia dari penjajahan.

Persamaan pandangan tentang keinginan memerdekakan diri dari penjajahan itu merupakan kesepahaman antara kelompok nasionalis dan ulama-ulama yang berada di pesantren. Dengan adanya kesepahaman ini, dalam proses selanjutnya akan terjadi proses berkolaborasi antara pemimpin pergerakan dengan para ulama yang berjuang gigih mengusir penjajah.

Di kota Surabaya, bersama dengan Kyai Haji Mas Mansyur seorang tokoh Muhammadiyah, Wahab Khasbullah mendirikan Nahdlatul Wathan (Ismail 2002, 30), (Kebangkitan Tanah Air) sebuah lembaga pendidikan bercorak nasional-moderat. Lewat Nahdlatul Wathan ia dapat merealisasikan ide-ide pendidikan. Yang tidak dapat dilupakan adalah sumbangan Wahab Khasbullah untuk kemerdekaan bangsa.

Di sekolah Nahdlatul Wathan inilah ide-ide patriotik kebangsaan bersemi. Bahkan atas dasar kecintaan pada kemerdekaan, Wahab Khasbullah menulis lagu berbahasa Arab berjudul "Laa Yal Wathan" yang dinyanyikan murid-muridnya sebelum pelajaran dimulai, ( Bruinessen 1994, 35) syair lagu ini kalau di-Indonesiakan berbunyi:

Wahai bangsaku, wahai bangsaku

Cinta tanah air bagian dari iman

Cintailah tanah air wahai bangsaku

Jangan kalian menjadi orang terjajah.

Sekolah Nahdlatul Wathan tidak hanya berdiri di Surabaya. Seperti halnya sekolah Muhammadiyah yang berdiri di berbagai daerah, sekolah bercorak dan berafisiasi dengan Nahdlatul Wathan juga berdiri di banyak tempat; Akhlakul Wathan di 
Semarang, Fa'ul Wathan di Gresik, hidayatul Wathan di Jember, Ahlul Wathan di Wonokromo dan Khitabul Wathan (Halim tt, 34).

Dengan berdirinya sekolah-sekolah ini, akar nasionalisme mulai digulirkan kepada para santri atau murid-murid yang bersekolah di situ. Pada akhirnya, sebuah kesadaran akan rasa cinta tanah air bersemi dalam ruang-ruang pendidikan yang diasuh oleh para guru yang kebanyakan adalah santri-santri yang lulus dari pesantren dan sekolah-sekolah Islam yang mulai berkembang dan menghasilkan alumni-alumni yang berjiwa nasionalis.

Sebelum konflik yang berkepanjangan antara kelompok tradisionalis dan modernis berlangsung, Wahab Khasbullah mendirikan suatu kursus perdebatan/kelompok diskusi yang dinamakan Tashwirul Afkar. Lewat Tashwirul Afkar inilah, Wahab Khasbullah mempertemukan pemuda-pemuda Islam dan ulama-ulama baik dari kalangan modernis maupun tradisionalis untuk bersama-sama membahas keilmuan Islam, seperti mazhab dalam Islam, ijtihad dan masalah-masalah keislaman yang dibicarakan dengan sangat cair.

Lewat jalur pendidikan dengan mendirikan Nahdlatul Wathan dan Tashwirul Afkar, Wahab Khasbullah membangun semangat nasionalisme para ulama dan meningkatkan kapasitas intelektual para pemuda. (Amin 2005, 29). Begitu juga setelah berdirinya NU yang berawal dari konflik antara kelompok muslim modernis dan muslim tradisionalis mengenai masalah Makkah yang dikuasai oleh kelompok Wahabi.

Wahab Khasbullah tetap menunjukkan jati dirinya sebagai seorang pembaharu. Di Tambak Beras, ia mendirikan Madrasah yang bernaung di bawah Pesantren Tambak Beras. Ide pendirian madrasah di lingkungan pesantren merupakan ide yang telah lama ia pikirkan. Pendirian madrasah di lingkungan pesantren bagi Wahab Khasbullah merupakan salah satu usaha memajukan pesantren agar tetap diterima dalam masa yang akan datang.

Sebagai seorang yang berasal dari "produk" pesantren, ide-ide Wahab Khasbullah patut disimak; mulai dari usaha mengadakan pembaharuan pendidikan Islam tradisional, ide kebangkitan ulama dengan mendirikan jami'iyah NU yang merupakan benteng kelompok tradisionalis yang paling kokoh. Dalam pendirian NU pun Wahab Khasbullah tidak melupakan usahanya untuk memajukan pendidikan di kalangan tradisonalis. Ismail (2005) menjelaskan sbb:

Konsisten dengan visi misinya, Nahdlatul Ulama selalu mencoba meluaskan kegiatannya dalam wilayah sosial agama, yaitu dengan mendirikan banyak madrasah dan memajukan sistem manajemen, membuat yayasan yang menaungi masjid, langgar dan pesantren, dan membantu meningkatkan kesejahteraan kaum miskin. Tahun 1929, Nahdlatul Ulama mendirikan organisasi termasuk Ma'arif yang bertugas mengkoordinasikan dan mengembangkan semua intitusi pendidikan yang dinaungi oleh Nahdlatul Ulama. 
Juga tidak kalah penting adalah ide-ide untuk kemerdekaan bangsa ini; pengorganisasian perjuangan, ide pendekatan golongan-golongan Islam dan "nasionalis", ide perlawanan terhadap segala bentuk penjajajhan, ide mencetuskan kemerdekaan dan mempertahankannya dan ide membangaun potensi nasional untuk kepentingan seluruh warga Republik Indonesia (Zuhri 1983, 106).

Dikotonomi antara Islam dan nasionalis di Indonesia merupakan stigma yang tidak mendasar. Nasionalisme adalah suatu rasa cinta tanah air, dalam hal ini, nasionalisme merupakan rasa yang dapat dilakukan oleh semua unsur masyarakat yang ada di Indonesia. Di masa kolonial Belanda, wujud nyata dari rasa nasionalisme adalah dengan usaha memerdekakan Indonesia.

Tulisan ini menunjukkan bagaimana usaha Ahmad Dahlan dan Wahab Khasbullah, dua founding father pendidikan Islam ini dalam memperjuangkan kemerdekaan Indonesia. Dengan adanya tesis ini, pendidikan Islam dapat menjadi pelopor bagaimana rasa cinta tanah air merupakan suatu pijakan untuk memajukan bangsa. Oleh karena itu, penulis memberi rekomendasi terhadap pendidikan agama Islam:

1. Islam adalah agama yang tidak melarang adanya kecintaan terhadap suatu bangsa yang bertujuan untuk memajukan rakyat an segenap tumpah darahnya.

2. Pendidikan Agama Islam dapat mengambil contoh dan hikmah bagaimana kedua tokoh kemerdekaan ini memperjuangkan kemerdekaan Indonesia dengan tidak melupakan semangat mereka yang diilhami atas ajaran Islam.

3. Pendidikan Agama Islam patut berbangga, karena dalam sejarah perjuangan bangsa ternyata memiliki kontribusi yang tidak sedikit di dalam memperjuangkan kemerdekaan Indonesia.

\section{Kesimpulan}

Pendidikan model Barat tidak dapat dipungkiri membawa pengaruh terhadap pembaharuan pendidikan Islam. Kasus Ahmad Dahlan dan Wahab Khasbullah dapat menjadi contoh bagaimana modernisasi pendidikan lewat model Barat membawa konsekuensi perubahan pendidikan Islam di Indonesia

Kita juga tidak dapat menafikan bagaimana para pembaharu pendidikan Islam ini dalam mendirikan sekolah-sekolah, mereka tidak melupakan usaha-usaha untuk menuju kemerdekaan Indonesia. Sosok Ahmad Dahlan dan Wahab Khasbullah adalah contoh 
figur-figur di kalangan santri yang sangat getol untu memperjuangkan kemerdekaan lewat sekolah dan organisasi yang mereka dirikan.

Ahmad Dahlan dan Abdulwahab Khasbullah adalah para pembaharu pendidikan Islam yang bekerja untuk mendidik anak bangsa untuk selalu sadar bahwa usaha untuk merdeka harus dipunyai oleh anak didiknya. Kedua orang inilah yang merupakan salah satu contoh bagaimana usaha kemerdekaan ini juga dibangun lewat bilik-bilik pesantren dan jendela-jendela sekolah agama yang didirikan oleh keduanya.

Rasa nasionalisme merupakan sebuah kesadaran diri keduanya dalam mengembangkan dan memajukan anggotanya. Nasionalisme juga yang dapat menjadikan keduanya bersemangat untuk membangun kesadaran umat Islam di Indonesia akan pentingnya kemadirian dan tidak terjerat dalam usaha-usaha penjajah untuk melemahkan rakyat Indonesia dari usaha menuju kemerdekaan Indonesia.

\section{DAFTAR PUSTAKA}

Ahmad, Fandy. "Pemikiran KH Ahmad Dahlan tentang Pendidikan dan Impelentasinya di SMP Muhammadiyah 6 Yogyakarta Tahun 2014/2015" dalam Jurnal Profetika Vol. 16, No 2, 2015: 144

Alfian. Politik Kaum Modernis:Perlawanan Muhammadiyah Terhadap Kolonial Belanda, Jakarta: Al-Wasath, 2010.

Amin, Masyhur. NU dan Ijtihad Politik Kenegaraannya, Yogyakarta; Al-Amin,1996.

Anam, Choirul.Pertumbuhan dan Perkembangan Nahdlatul Ulama, Sala; Jatayu,1985.

Azizatun Ni'mah, Zetty. "Pemikiran Pendidikan Islam Perspektif KH Ahmad Dahlan (1869-1923 M) dan KH Hasyim Asy’ari," dalam Jurnal Didaktika Religia Vol. 2, No. 1, 2014: 136.

Azra, Azyumardi. Jaringan Ulama: Timur Tengah dan Kepulauan Nusantara abad XVII dan XVIII, Bandung: Mizan, 1998.

Surau; Pendidikan Islam: Tradisionalis dalam Transisi dan Modernisasi (Jakarta; Logos Wacana Ilmu, 2003)

Pendidikan Islam; Tradisi dan Modernisasi Menuju Millenium Baru, Jakarta; Logos, 2002.

Bruinssen, Martin Van. NU, Tradisi, Relasi Kuasa, Pencarian Makna Baru, Yogyakarta; LkiS, 2015.

Chaidar, Al dan Herdi Sahrasad. "Negara, Islam dan Nasionalisme Sebuah Perspektif" dalam Jurnal Kawistara Vol. 3, No. 1, 2013: 41. 
Dahlan, Muh."KH Ahmad Dahlan Sebagai Tokoh Pembaharu."Dalam Jurnal Adabiyah Vol XIV, No 2, 2014: 123.

Daulay, Haidar Putra. Historisitas dan Eksistensi Pesantren, Sekolah dan Madrasah, Yogyakarta: Taiara Wacana, 2001.

Daya, Burhanudin. Gerakan Pembaharuan Pemikiran Islam; Kasus Sumatera Thawalib, Yogyakarta; Tiara Wacana, 1995.

Dhofier, Zamakhsyarie. Tradisi Pesantren; Studi tentang Pandangan Hidup Kyai, Jakarta; LP3ES, 2014).

"Sekolah Al-Quran dan Pendidikan Al-Quran di Indonesia” Dalam Ulumul Qur'an Volume III, No.4.Th. 1992.

“Hasyim Akhirnya Pilih Mega” di Republika, No.119 tahun ke 12, Jumat, 7 Mei 2004.

Geertz, Clifford. The Religion of Jav, Chicago; University of Chicago Press, 1976.

Goncing, Nurlina. "Politik Nahdlatul Ulama dan Orde Baru dalam Jurnal The Politics"Vol.1, No. 1, 2015: 61

Halim, Abdul. Sejarah Perjuangan Kiai Wahab Khasbullah, Bandung; PT Baru,tt.

Ismail, Faisal. Islamic Tradisionalism in Indonesia; A Study of Nahdlatul Ulama, Jakarta, Litbang Depag, 2002.

Jainuri, Achmad. Ideologi Kaum Reformis; Melacak Pandangan Keagamaan Muhammadiyah Periode Awal, Surabaya; LPAM, 2002.

Latif, Yudi. Genealogi Inteligensia: Kekuasaan Inteligensi Muslim Abad XX, Jakarta: Prenada, 2013.

Lubis, Arbiyah. Pemikiran Muhammadiyah dan Muhammad Abduh (Jakarta; Bulan Bintang, 1995)

Ma'arif, Ahmad Syafii.“Islam dan Pancasila Sebagai Dasar Negara: Studi Tentang Perdebatan Konstituante, ” Bandung: Mizan, 2017.

Maksum. Madrasah Sejarah dan Perkembangannya, Jakarta; Logos,1999.

Masfiah, Umi. “ Pemikiran Pembaharuan KH Abdulwahab Chasbullah terhadap lahirnya Nahdlatul Ulama: Journal Ihya Ulum Al-Din” Vol. 18, No. 2, 2016: 216

Mukodi "Islam Abangan dan Nasionalisme Komunitas Samin di Blora." Walisongo: Jurnal Penelitian Sosial Keagamaan, Vol. 24, No. 2, 2016: 379

Mulkhan, Abdul Munir. Pemikiran K.H. Ahmad Dahlan dan Muhammadiyah dalam Perspektif Perubahan Sosial, Jakarta; Bumi Aksara, 1990. 
Nyufi Cara Baru; Kiai Ahmad Dahlan dan Petani Modernis. (Jakarta; Serambi Ilmu Semesta, 2003)

Noer, Deliar. Gerakan Modern Islam di Indonesia 1900-1942, Jakarta; LP3ES,1996.

Peacock, James L. Gerakan Muhammadiyah Memurnikan Ajaran Islam di Indonesia, Yogyakarta: Suara Muhammadiyah, 2017.

Rahardjo, Dawam. Intelektual Intelegensia dan Perilaku Politik Bangsa; Risalah Cendekiawan Muslim, Bandung; Mizan, 1999.

Ricklefs M.C. Mengislamkan Jawa: Sejarah Islamisasi di Jawa dan Penentangnya dari 1930 sampai sekarang, Jakarta: Serambi, 2013.

Saiman, Weinata. Gerakan Pembaruan Muhammadiyah, Jakarta; Pustaka Sinar Harapan, 1995.

Setiawan, Farid. Genealogi dan Moderniasasi Sistem Pendidikan Muhammadiyah 19111942, Yogyakarta:Semesta Ilmu, 2015.

Shihab, Alwi. Membendung Arus; Respon Gerakan Muhammadiyah Terhadap Penetrasi Misi Kristen di Indonesia, Yogyakarta; Suara Muhammadiyah, 2016.

Steenbrink, Karel A. Pesantren, Madrasah dan Sekolah, Jakarta; LP3ES, 1994.

, Beberapa Aspek Tentang islam di Indonesia Abad ke-19, Jakarta; Bulan Bintang, 1987.

Suminto, Aqib. Politik Islam Hindia Belanda, Jakarta; LP3ES, 1996.

Syarif, Umar " Gerakan Pembaruan Pendidikan Islam:Studi Komparasi Pergerakan Islam Indonesia Antara Syech Ahmad Surkatiy dan KH Ahmad Dahlan” Dalam Jurnal Reflektika Vol 13, No 1, 2017: 76

Wahyudi, Yudian. Islam dan Nasionalisme: Sebuah Pendekatan Maqashid Syariah, Yogyakarta: UIN Suka Press, 2006.

Zuhri, Saifuddin. Kyai Wahab Khasbullah Bapak dan Pendiri NU, Yogyakarta; Pustaka Falaakiyah, 1983. 